\title{
Teaching and learning Oral Radiology via the social medium WhatsApp
}

\author{
Glaucia Nize Martins Santos*; André Ferreira Leite*; Paulo Tadeu de Souza Figueiredo*; Nilce Santos \\ de Melo*
}

* Department of Dentistry, Health Sciences Faculty, University of Brasília, Brasília

Recebido em 06/11/2016. Aprovado em 15/01/2017.

\begin{abstract}
Social media can be defined as Internet-based applications that allow the widespread creation and exchange of user-generated content. The ease with which social media can be accessed through numerous mobile devices encourages medical educators to use social media to share content with students outside the classroom. The aim of this study was to introduce WhatsApp as a teaching tool in an Oral Radiology course. The secondary objective was to assess students' attitudes towards the use of this innovative tool in teaching of dentistry. In the first semester of 2016, 30 second-year undergraduate dental students at the University of Brasília were provided with weekly quizzes via a WhatsApp discussion group. The quizzes consisted of a tomographic or radiographic image from a real clinical case and a multiple-choice question. At the end of the semester students' attitudes were assessed using a satisfaction questionnaire. The results showed that students had a positive attitude towards the use of WhatsApp and considered it had helped them to learn about Oral Radiology. In conclusion, this technology can improve the way material is taught, since educators are prepared to develop better learning environments and students are concerned about the potential use of the social media in education.
\end{abstract}

Descriptors: Social Networking. Education. Communication. Radiology. Dentistry.

\section{INTRODUCTION}

Social media are defined as Internet-based applications in which user-generated content is created and exchanged by large numbers of people. The ease with which students can assess social media through mobile devices, such as smartphones, tablets, laptops and e-readers, and the increasing amount of time they spend doing so encourages medical educators to use these media to share educational content outside the classroom $^{1}$.

The functions of smartphones - Internet browsing, email access, high-quality camera and a wide range of applications, popularly known as "apps" - are innovative tools that can be used for mobile learning (m-learning). Conventional 
blogging sites and micro-blogging tools such as Twitter, social networks as Facebook, video content-sharing sites as YouTube, cloud storage sites like Google Docs, and Internet-based communication software as Skype and WhatsApp show great potential to improve medical education, as they allow health care students to access resources conveniently and easily, and communicate quick and effectively ${ }^{2-4}$.

Because learning via social media forces students to interact and collaborate to solve problems it deepens the learning experience ${ }^{5,6}$. Active learning is an instructional approach in which students are required to participate in the learning process by interacting during the course of meaningful activities that lead them to think about their attitudes. Active learning is a valuable tool that has potential to enhance learning via social media applications.

The advantages of introducing social media into the learning process include the opportunities for collaboration amongst users, creation of personal content via different media and sharing of individual work, as well as construction of new approaches to research ${ }^{7}$. For educational purposes, social media combines a strong social component with user-generated content in the forms of text, video and photographs as well as comments, tags, and ratings $^{8}$. The main value of social networking applications is as an egalitarian, efficient means of spreading information relevant to pedagogical goals; they also allow educator to create a sense of social learning and engagement within a community ${ }^{9}$.

Instant Messaging (IM) is a term used to describe the way users communicate instantly via their mobile devices, mainly smartphones, and it has become one of the most popular methods of communication amongst health professions ${ }^{10}$. Nowadays, the most popular messaging application is the WhatsApp Messenger, which has more than one billion users worldwide. WhatsApp was designed to replace short message service (SMS) with an Internet-based platform thus allowing users to avoid the international fees that mobile providers charge ${ }^{11}$.

Despite the increasing use of these creative applications for educational purpose in the university environment, dental courses still rely on traditional forms of teaching. The primary aim of this study was to introduce the social medium WhatsApp as a teaching tool in an Oral Radiology course. The secondary aim was to evaluate students' attitudes towards the use of this innovative tool as part of their dental studies.

\section{MATERIALS AND METHODS}

This descriptive study was approved by the ethics committee of University of Brasília under the number CAAE 42277115.3.0000.0030. The social medium WhatsApp was used to create a discussion group involving 30 second-year undergraduate dental students of University of Brasília who were following an Oral Diagnosis course, covering oral and maxillofacial anatomy, interpretation of radiographic bone lesions and dental caries, and identification of tooth anomalies, cysts and neoplasms. The participation in the discussion group started after the written informed consent form agreement, and was not a requirement of the course. Participants consented to make their cell phone numbers available to the researcher, who undertook not share them with anyone outside the research team, in order to ensure participants' privacy.

Three titular professors and two tutors were also added to this Internet-based discussion group via smartphone. During the first semester of 2016, the content of the Oral Radiology course was delivered face-to-face by the titular professors. During the same period, the tutors used WhatsApp to publish a weekly quiz, with one question per quiz. The quizzes were published four to six hours after face-to-face classes and covered the same material. Each quiz consisted of a tomographic or radiographic 
image from a real clinical case and a multiplechoice question. Students could also use the platform to ask questions about issues discussed in class.

The quizzes were created in the form of Power Point slides, saved in .jpeg format and shared with the WhatsApp discussion group. After students had posted their answers, the tutors started a discussion based on the images shown in the quiz as a way of encouraging students to review the material covered in class. Every message sent was counted, including mistakes and successes achieved by the students in each activity as well as their contributions to discussions.

At the end of the semester, a satisfaction questionnaire consisting of 12 questions in Likert scale format and an open point-of-view question, was applied to the students, to assess participants' attitudes to use the app for Oral
Radiology education and get a feedback about the presentation and content of the quizzes. The satisfaction questionnaire was free-based in the TRIL questionnaire (Trierer Inventar zur Lehrevaluation - educational evaluation questionnaire of Trier University) by Gläßer et al. (2002, apud Nkenke et al. 2012). ${ }^{12}$

\section{RESULTS}

All students on the course opted to join the WhatsApp Oral Radiology discussion group and all had mobile phones connected to the Internet. Weekly quizzes were made available over a fourteen-week period. Twenty-eight (17 women; 11 men) of the 30 participating students added comments to discussions of at least two quizzes. The percentage of students participating in a quiz, which ranged from $66.67 \%$ for the first quiz to $23.33 \%$ for the penultimate quiz, is shown in figure 1.

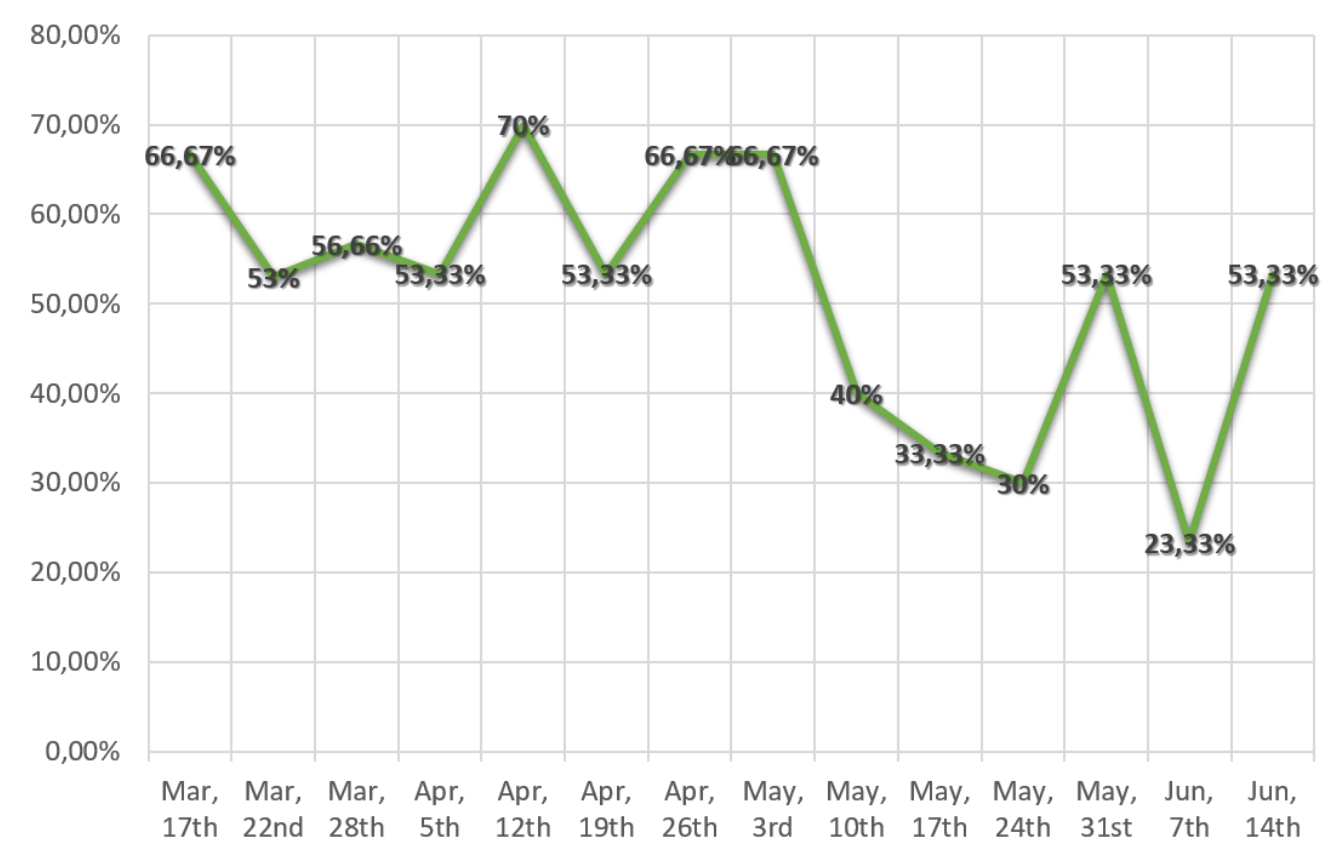

Figure 1. Response rates for all quizzes uploaded during the semester.

Students made a total of 372 posts, quizzes, comments on the content discussed, consisting of right and wrong answers to the questions about other oral radiology issues and 
marketing of oral radiology lectures. There were more correct answers to quiz questions (37, $9.43 \%$ of posts) than incorrect answers (17, $4.34 \%$ of posts) and quizzes related to oral and maxillofacial anatomy questions had more correct answers. There were far more posts discussing the topics than there were correct or incorrect answers to quiz questions.

At the end of the fourteen-week period, a satisfaction questionnaire was applied to the students. The questionnaire covered students' attitude towards receiving and answering quizzes through the Instant Messaging discussion group. Responses were given using a Likert scale ranging from 1 (I totally disagree) to 5 (I totally agree)

The questions were free-based in the TRIL questionnaire (Trierer Inventar zur Lehrevaluation - educational evaluation questionnaire of Trier University) by Gläßer et al. (2002, apud Nkenke et al. 2012) $)^{12}$ which consists in a six topics modular German-language questionnaire for the evaluation of courses at university, not validated in Portuguese language (table 1).

Table 1. Responses to the questions adapted from TRIL (Trierer Inventar zur Lehrevaluation Educational evaluation questionnaire of Trier University)

\begin{tabular}{|c|c|c|c|}
\hline & \multicolumn{3}{|c|}{ Instant Messaging group } \\
\hline & $\mathbf{n}$ & Mean & SD \\
\hline \multicolumn{4}{|l|}{ Topic 1 Structure and Didactics } \\
\hline Were the questions clear and objective? & 25 & 4.08 & 0.57 \\
\hline $\begin{array}{l}\text { Was the presentation of material (elements' organization and size, colors, and } \\
\text { font size) conducive to learning? }\end{array}$ & 25 & 4.44 & 0.50 \\
\hline Did the sequencing of the questions make learning easier? & 25 & 4.08 & 0.75 \\
\hline Was the frequency of activities (weekly) appropriate? & 25 & 4.24 & 0.87 \\
\hline \multicolumn{4}{|l|}{ Topic 2 Motivational skills of the lecturer } \\
\hline Was having an online teacher is important to you? & 25 & 4.68 & 0.85 \\
\hline \multicolumn{4}{|l|}{ Topic 3 The extent to which the lecturer created a context conducive to learning } \\
\hline Do you think the activities were a good fit with the face-to-face material? & 25 & 4.76 & 0.83 \\
\hline Was the content of online debate useful? & 25 & 4.56 & 0.86 \\
\hline \multicolumn{4}{|l|}{ Topic 4 Practical relevance of the course } \\
\hline Were the images posted helpful? & 25 & 4.48 & 0.65 \\
\hline Did you learn new information from the content shared via WhatsApp? & 25 & 4,52 & 0.87 \\
\hline \multicolumn{4}{|l|}{ Topic 5 Questions on different additional aspects } \\
\hline Do you think that learning via WhatsApp is efficient? & 25 & 4.00 & 1.00 \\
\hline \multicolumn{4}{|l|}{ Topic 6 Homework } \\
\hline Did the content of the activities help you to remember information? & 25 & 4.00 & 1.11 \\
\hline Were the questions easy? & 25 & 3.08 & 0.70 \\
\hline
\end{tabular}

The Topic 1 responses showed that students were satisfied with the virtual environment provided in WhatsApp; they agreed it was didactic, clear, objective and in a good frequency. Topic 2 responses revealed that having a teacher available online was very important to the students. Topic 3 responses showed that students agreed that the quizzes matched the face-to-face content and found group discussions useful. Topic 4 consisted of two questions about the practical relevance of the course and responses indicated that students 
appreciated receiving the selected images via WhatsApp and felt that the images had helped them to learn new information. In responses to Topic 5 the majority of students rated WhatsApp as an effective educational tool, although the variance in responses was very high. Responses to Topic 6 showed that students did not agree that social media helped them to remember information and that they had found the questions really hard.

At the end of the questionnaire students were encouraged to provide additional comments about the use of WhatsApp, and 23 (92\%) did so. These responses are presented in the discussion below.

\section{DISCUSSION}

The main findings of this study are that students' evaluated the WhatsApp discussion group positively and considered it helpful to their Oral Radiology course. It is important to highlight that the participation level was lower than expected by educators, even though all students had easy access to mobile phones and the Internet.

In 1987 Chickering and Gamson ${ }^{5}$ proposed seven principles of good teaching and learning in colleges, including high expectations, good communication between students and faculty, reciprocity and cooperation among students, active learning and prompt feedback. Also time on task and respect to talents and ways of learning diversity should be emphasized. WhatsApp and other instant messaging applications meet these criteria for best practice in education and have a beneficial effect on learning ${ }^{13,14}$. We found that use of social media increased the amount of contact between professors and students and this was cited by some participants as the main benefit:

“(...) Easier communication makes it easier to resolve queries.", "The main point is communication. In the app, information has no interruption which helps us to enhance our knowledge through ordinary chats.", "An easy and quick access tool. It shows great interactivity."

Cooperation between students was also observed as they created and shared content amongst themselves in the WhatsApp group. It gave value to the students' time spent in researching and studying:

"Students could ask questions and share contents such as scientific articles, slides, images, etc”, “(...) the debate encouraged us to think more and better assess dental radiographies."

In addition, tutors responded quickly to students in this dynamic learning environment ${ }^{15}$. Prompt feedback made students feel more comfortable and secure about their posts, thus enhancing the learning experience:

"It induced us to study more.", "Very accessible information and interactive debate", "Questions could be resolved as soon as they arose. It helped to remember the content."

Responses to the satisfaction questionnaire confirmed that the WhatsApp discussion group complied with the principles of good teaching and learning cited above. Students mentioned that they liked working in group, getting feedback quickly, being encouraged to study independently and, in particular, having a teacher available online:

"The content and deadline for learning were excellent, including the debates.", "It was a quick way of getting help with the material covered in face-to-face classes.", "It was good for evaluating the other students' level (...) and for seeing if the group's opinion was the same as mine.", "The WhatsApp discussion group gave us a way of going through information about radiology during the week.", "The main positive point was the opportunity to review the content in an easy, objective and quick way (...)", "The activity was good way of reminding us about 
diagnostic material and encouraging us to go through it again.", "It was good to test what we had learned and it encouraged us to search for the right answers. ”, “(...) Having an online teacher is VERY IMPORTANT.",

"It was great to have an online teacher to resolve queries (...)"

The availability of a teacher was a particular advantage to students who were too scared or shy to ask questions in class. It is important to highlight that the majority of the students were positive about working in a group because it allowed them to compare their performance with that of their peers. This can be explained by the Hawthorne effect, a student's productivity is not determined by his or her physical capacity but by social interaction and group expectations prevailing in the university environment $^{16}$. Nevertheless, one student disapproved of the group learning aspect of the use of WhatsApp:

"Working in a group was not good."

Gonzalez and Gadbury-Amyot (2016) ${ }^{17}$ evaluated dental students' use and perceptions of the social medium Twitter for teaching and learning as part of an Oral Radiology course. Twitter sessions were perceived as helpful and they improved instructor accessibility. In our study, most of the students rated WhatsApp an efficient method of learning, confirming that they are positive about use of social media in education:

"I think it is an instructive and accessible method of learning.", "It was great to see more clinical cases relating to the material we were learning."

November ${ }^{18}$, an international leader in education technology, stated that the world had recognized the power of social media to provide worldwide information and communication. Educators have a fundamental role in understanding the potential of these tools and offering genuine experiences to students and are capable to widespread their own personal learning networks. Teachers should connect students to real-world problems and provide examples of how to use the most powerful social media tools to expand the boundaries of learning. Dental faculty members have indicated that they are uncertain about how to use social media in teaching and learning. This study investigated the first use of a WhatsApp discussion group, a learning tool not previously used in Oral Radiology education. Participants complained about multiple-choice questions because it seemed that the responses were merely copies, which demonstrates educators' lack of experience in creating a pedagogical environment in social media. Results suggest that the best use of WhatsApp may be as an online question and answer tool rather than for quizzes:

"Because the quizzes were built as multiplechoice questions, the repetition of the responses seemed that students were copying from one another.", "Many times it seemed that we were simply copying the answers."

To cope with the challenges that rise of technology poses, universities must aim to provide professional development resources, such as programs to enhance faculty members' pedagogical skills ${ }^{19}$. Our study demonstrates that to meet the demands of the "digital generation" educators must increase their engagement with students' preferred communication tools, focusing on achieving a deeper understanding of how they can be used to improve students' learning and foster their creativity and selfdirection. It has been recognized that the most difficult challenge facing dental institutions is the development of new approaches to teaching and learning and the integration of new technologies into classrooms and clinics ${ }^{19}$.

Many students fail to see the educational value tools they use routinely for other purposes. Dental students associate social networking services with private discussions and not with dental school interactions ${ }^{20}$. Students should 
been given explicit guidance on how to make best use of social media in their education and set specific objectives ${ }^{18}$.

In our study the participation rate for social media quizzes ranged from $66.67 \%$ for the first quiz to $23.33 \%$ for the penultimate quiz. This may be due to several factors. First, the variation may be directly related to the timing of University exams; participants reported that they had not had enough time to keep posting on the social media quizzes whilst revising for exams:

"We could not answer all the quizzes because we have many other disciplines to study.", "We had problems finding the answers to the quizzes due to lack of time to search and study. It is not a methodological fault.", "Often it was hard to find time to search, study and post the answers." "It was very hard to find time to answer to the quizzes posted by the tutor."

Another possibility is that questions got harder over the course of the fourteen-week study period. One student stated that questions did not fit with the content delivered in class, and the lower mean value of the satisfaction questionnaire was related to the quizzes' level of difficulty (table 1):

"Questions were too hard, incompatible with the face-to-face level content."

Nielsen ${ }^{21}$ argued that although students access numerous multimedia sites such as YouTube, they often avoid aspects of the Internet that they perceive as "difficult" for fear of wasting time. Lack of interest and lack of reward (in the form of better scores, in the discipline) may also explain the decrease in participation over the study period. In other words, the students may not have found the learning environment created by the educators sufficiently attractive to encourage them to keep posting when the questions were challenging.

Social behavior has changes since mobile devices and social media became more accessible. Society has shifted from the "attention age" to the "information age". Levy concluded "constantly being accessible makes you inaccessible" 22 because extensive use of social media promotes a state of partial attention. Social media allow people to review interpersonal relations and group identity, resulting in an unfiltered, spontaneous, and potentially high-impact style of learning ${ }^{23}$. Nevertheless use of mobile phones during lectures, tests and examinations has to be regulated in order to protect students' privacy and ensure that no inappropriate communication takes place ${ }^{15}$.

Technology, including mobile devices, has permeated our daily lives and gives us unlimited access to communication and information. All the participants in our study, which was carried out in a public Brazilian University, had smartphones connected to the Internet; however, three participants stated that the posted images were not clear, presumably due to the poor quality of their mobile phones:

"I suppose some images were not clear due to the quality of my smartphone.", "Some images were not good quality.", "Some images were not clear enough."

Willemse and Bozalek ${ }^{24}$ described students' and educators' opinions about the benefits of using mobile devices in an undergraduate nursing program. This study, carried out in Western Cape Province, South Africa, emphasized that only a limited number of students were using smartphones. The researchers recognized that some students were not able to download WhatsApp or Facebook because of the limited capability of their mobile device. Although not all students have smartphones of sufficient quality to allow them to benefit from educational social media applications, the potential benefits of using social media as learning tools are particularly relevant in resource-poor contexts, because they are a free service on mobile phones and computers $^{11}$.

The drawbacks of m-learning are the risk of inappropriate and unprofessional online behaviors, 
such as patient privacy violations, especially if student anonymity is preserved ${ }^{25}$. Another disadvantage of WhatsApp is the need to have a connected mobile phone; this means that all participants have access to each other's mobile phone numbers. It also means that students can exchange messages or phone calls 24 hours a day, seven days a week. It is important to highlight that there are plenty of other options that may be used as online interactive tool in an educational context and that the effective use of mobile devices in education depends on accessibility, connectivity, infrastructure and technical support.

The limitations to this study are that it was carried out in a single dental school and the sample was small, so the generalizability of the results is limited. A further limitation is that we did not assess whether participating in the WhatsApp discussion group increased students' knowledge of the topics covered.

\section{CONCLUSION}

The social medium WhatsApp was used as a teaching tool for dentistry students following an Oral Radiology course. Teachers need access to better instruction about the demands of the "digital generation" if they are to be able to develop interesting learning environments and know how to use social media tools effectively to expand the boundaries of learning. Students reacted positively to the introduction of this collaborative tool, although participation decreased over time. There are many possible reasons for this: lack of time, lack of reward and the difficult of the tests. More research is needed into ways of using collaborative spaces for participatory learning.

\section{RESUMO \\ Ensinando e aprendendo radiologia oral via mídia social WhatsApp}

Mídias sociais podem ser definidas como um grupo de aplicativos baseados em Internet que permitem a criação e troca de conteúdos gerados pelo usuário de forma bastante expandida. A facilidade de as mídias sociais serem acessadas em dispositivos móveis encoraja educadores da área de saúde a compartilhar nessas mídias conteúdos que vão além da sala de aula. O objetivo desse estudo foi introduzir a mídia social WhatsApp como uma ferramenta de ensino no curso de Radiologia Oral. Como segundo objetivo, as atitudes dos estudantes ao utilizar essa nova ferramenta durante a graduação em Odontologia foram avaliadas. No primeiro semestre de 2016, quizzes semanais foram disponibilizados em um grupo de discussão no Whats App, criado com 30 alunos do segundo ano de Odontologia da Universidade de Brasília. Os quizzes eram compostos por uma imagem radiográfica ou tomográfica de um caso clínico real e uma questão de múltipla escolha. Ao final do semestre, avaliou-se o comportamento dos estudantes por um questionário de satisfação. $\mathrm{O}$ estudo mostrou que os alunos têm atitude positiva em relação ao uso do WhatsApp e o consideraram útil para auxiliar o aprendizado de Radiologia Oral. Em conclusão, essa tecnologia é capaz de aprimorar a forma como os conteúdos são ensinados, desde que os educadores estejam preparados para desenvolver melhores ambientes de aprendizado e os estudantes estejam conscientes sobre o potencial uso das mídias sociais para educação.

Descritores: Rede Social. Educação. Comunicação. Radiologia. Odontologia.

\section{REFERENCES}

1. Kaplan A, Haenlein M. Users of the world, unite! The challenges and opportunities of social media. Bus Horizons. 2010;53:59-68.

2. Gupta B, Koo Y. Applications of mobile learning in higher education: An empirical study. Int J Educ Dev Using Inf Commun Technol. 2010;6(3):75-85.

3. Mosa A, Yoo I, Sheets L. A systematic review of healthcare applications for smartphones. BMC Med Inform Decis Mak. 2012;12:67.

4. Johnson L, Levine A, Smith R, Stone S. The 2010 Horizon Report. Austin, TX: The New Media Consortium; 2010. 
5. Chickering A, Gamson Z. Seven principles for good practice in undergraduate education. American Association for Higher Education. 1987.

6. Michael J. Where's the evidence that active learning works? Adv Physiol Educ. 2006; 30(4):159-67.

7. Crook C, Fisher T, Graber R, Harrison C, Lewin C, Cummings J, et al. Implementing Web 2.0 in secondary schools: impacts, barriers, and issues. United Kingdom: Becta; 2008. 139 p.

8. Cormode G, Krishnamurthy B. Key differences between Web 1.0 and Web 2.0. First Monday 2008;13(6):1-17.

9. Regenberg A. Tweeting science and ethics: Social media as a tool for constructive public engagement Am J Bioeth. 2010;10(5):30-1.

10. Khatoon B, Hill K, Walmsley A. Instant Messaging in Dental Education. J Dent Educ. 2015;79(12):1471-8.

11. Yeboah J, Ewur G. The impact of WhatsApp messenger usage on students performance in Tertiary Institutions in Ghana. J Educ Pract. 2014;5(6):157-64.

12. Nkenke E, Vairaktaris E, Bauersachs A, Eitner S, Budach A, Knipfer C, et al. Spaced education activates students in a theoretical radiological science course: a pilot study. BMC Med Educ. 2012;12(32). (cited 2016 July, 15). Available from: http://www. biomedcentral.com/1472-6920/12/32.

13. Makoe M. Exploring the use of MXit: A cell phone social network to facilitate learning in distance education. Open Learning 2012;25 (3):251-7.

14. Nicholson S. Socialization in the "Virtual Hallway": Instant messaging in the asynchronous web-based distance education classroom Internet and Higher Education 2002;5(4):363-72.

15. Dewah P, Mutula S. Mobile phone access and use among students at the National University of Technology (NUST)
Bulawayo, Zimbabwe: Implications for academic integrity Innovation. Journal of Appropriate Librarianship and Information Work in Southern Africa: Information Ethics 2013;46:150-65.

16. McCambridge J, Witton J, Elbourne DR. Systematic review of the Hawthorne effect: New concepts are needed to study research participation effects. J Clin Epidemiol. 2014; 67(3):267-77.

17. Gonzalez S, Gadbury-Amyot C. Using Twitter for Teaching and Learning in an Oral and Maxillofacial Radiology Course. J Dent Educ. 2016;80(2):149-55.

18. November A, Mull B. How Twitter can be used as a powerful educational tool Creative Commons: NovemberLearning.com; 2012 [cited 2016 July, 15].

19. Valachovic RW. Commission on change and innovation in dental education. ADEA Charting Progress. 2006.

20. Stein CD, Eisenberg ES, O'Donnell JA, Spallek H. What dental educators need to understand about emerging technologies to incorporate them effectively into the educational process. J Dent Educ. 2013;78(4):520-9.

21. Nielsen J. College students on the web. [Internet\}. 2010 (cited 2016 Jun 28). Available from: www.nngroup.com /articles/college-students-on-the-web/.

22. Levy S. (Some) attention must be paid! Carrying a Black-Berry is admitting that your commitment to your current activity is only partial. Newsweek. 2006 March 27:16.

23. Fuchs C, Hofkirchner W, Schafranek M, Raffl C, Sandoval M, Bichler R. Theoretical foundations of the web: cognition, communication, and cooperation - towards an understanding of web 1.0, 2.0, 3.0. Future Internet 2010;2(1):41-59.

24. Willemse JJ, Bozalek V. Exploration of the affordances of mobile devices in integrating theory and clinical practice in an 
undergraduate nursing programme. Correspondência para:

Curationis 2015;38(2):Art. \#1510, 10 pages. Glaucia Nize Martins Santos

25. Chretien K, Greyson S, Chretien J, Kind T. e-mail: nize.gal@gmail.com

Online posting of unprofessional content by

University Hospital of Brasília.

medical students. JAMA. 2009;302(12)

SGAN 605/606 Avenida L2 Norte

:1309-15.

70840-901 Brasília/DF 